\title{
The Analysis of the Opinions of School Directors about Their Knowledge of the Curriculums and Their Support and Control in the Implementation
}

\author{
Hasan Huseyin Ozkan \\ Department of Curriculum and Instruction, Suleyman Demirel University, Turkey
}

Copyright $(2016$ by authors, all rights reserved. Authors agree that this article remains permanently open access under the terms of the Creative Commons Attribution License 4.0 International License

\begin{abstract}
This study analyses the opinions of school directors related to their levels of recognition, comprehension and explanation, along with their support and their supervisory duties in the process of the implementation of the curriculum. Although this study is designed appropriately to the qualitative research design, phenomenological research design is used in some cases which are well known but a deep comprehension cannot be attained. The research group is determined in terms of simple sampling method and consists of 28 secondary school directors. . The data collected through interviews is analyzed through content analysis. According to the results obtained, in terms of recognition, comprehension and explanation of the curriculum, the school directors are aware of the elements of the curriculum: Objective $89 \%$, Evaluation $75 \%$, Learning situations $57 \%$ and Content $54 \%$. In terms of supports given for the implementation of the curriculum, the school directors stated that they had provided support in providing teaching tools, in creating and improving the learning, environment, in conduction meetings with teachers, supporting, encouraging and guiding them, in teaching planning and content organization. In terms of the task of controlling curriculum implementation, the results show that school directors fulfilled their duties in inspection of teacher, in compliance inspection of teaching aids, in inspection of the instructional plan, in the level of success on objectives, in student satisfaction, in inspection of learning environments, etc.
\end{abstract}

Keywords School Directors, Curriculum, Comprehension of Curriculum, Task of Controlling the Curriculum

\section{Introduction}

In the education process, one of the most important burdens in fulfilling the duties expected from school itself is undertaken by school directors. Despite a great organization, well-developed curriculums and qualified teaching staff, in the absence of a modern school director, it will not be able to achieve expected benefits of educational activities. Therefore, a well-trained in all aspects of school directors can carry on the educational duties with a success. In this process, a school director is charged with performing responsibilities such as; managing the other staff in the school (officers, teachers, servants, deputy principals, etc.) effectively, regulating the physical conditions of a school, developing good relationships with surroundings, following students' improvement in every respect. Hence, school directors have a crucial role carrying out educational activities efficiently.

The basic duties, powers and responsibilities of the school directors are to carry out the objectives of the school. The primary task of a school director is to manage, evaluate and develop the objectives of the school properly. The fulfillment of this primary task is closely related to the school directors' knowledge of the curriculum, their support in the implementation of the curriculum and their role in the evaluation and controlling of the curriculum. The school directors' comprehension of the curriculum, the support they provide the teachers in the implementation of the curriculum, their determination in the use of school facilities in the successful implementation of the curriculum, and their tasks related to the evaluation and controlling of teaching process may provide important contributions to the improvement of teaching activities. Moreover, this situation will also contribute to the definitions which support the idea that curriculum development process is perpetual and can be performed through application.

One of the primary tasks in teaching-learning process is to increase quality of instruction. The school directors have substantial duties and responsibilities related to the improvement of quality of instruction. Lezotte [1] defines school as a place where there is voluntariness related to 
commitment to the instructional goals, priorities, assessment procedures and accountability whereas, for Johnson[2], the school is a place where teachers and students are valuable members of the school community and where student success has an important place. Therefore, the school occupies a significant place, which increases the expectations from school.

In the recent years, the world faced many scientific and technological developments. However, the schools did not develop in line with these scientific and technological developments: The schools are not able to meet what is expected from them; they are not capable of training individuals who can stand on his own foot; they are not successful in training individuals who need more common qualities in the globalized world. These facts suppress the school directors for a more effective school [3-8]. Because an effective school is a school which enables providing students' cognitive, affective and psychomotor development and creating a learning environment optimally [70]. Effective schools use appropriate physical environment, teaching tools and all other school resources efficiently for the success of students. In this sense, school directors must devote themselves to their jobs, must work hard when performing their legal duties and responsibilities, must develop a better vision and mission, must improve themselves, must learn and apply what is needed for the increment of the student success, must be able to perform required guidance and must be able to control. The directors of the effective schools should be leaders who are open to innovation, who support personal development, who improve personal relations in the school, who create vision, mission and expectations and who contribute to the improvement of quality of instruction through their behaviors which instill responsibility [9-11, 18, 23].

Whatever type and stage it has, the largest share in terms of success belongs to school directors [47-51]. The school director plays a significant role in formation of school culture by allowing students and teachers to connect the school [52]. In order to school directors fulfill these tasks successfully; they have to take into consideration teachers' and other staff's roles and expectations. By this means, healthy communications at the school will be established, school culture will take a form $[53,54]$ and an effective learning environment will be provided. On behalf of ensuring an efficient educational environment, school directors should undertake substantial roles like; sourcing $[55,56]$, supporting teachers in lesson planning process [57], establishing a link between sub-units with the top units in their schools, and making an effort for the development of a learning culture among students [5]. Besides, by their efforts and entrepreneurial spirit and ethical values they exhibit, school directors should provide the highest level of learning and share school's vision to individuals and organizations within the school and outside the school [58].

Considering the work done with school directors, insight about what features a successful school director needs to have can be gained. Hallinger and Murphy [58] in their study about examining the behavior of school directors, effective school directors have a role in the establishment of an effective communication in the school environment stated that, the creation of an open and fair discipline policy, the organizing for the teaching, occurring a positive effect on students' behavior and success, improving academic achievements in schools, creating a common vision and the power-sharing. Gümüşeli [59] in his study which examining school directors who can manage modern schools, their sufficiency levels in the meaning of leadership and their characteristics, showed that school directors should, prepare plans and programs that will shape the feature of the schools and apply them, renew schools' organizational and management structure according to changing demands and expectations of society, arrange school activities according to the principles of learning and teaching, take student achievement to the center, and obtain ethical and legal regulations as guidance in their work. Çelikten [60] states that school directors should have roles some like instructional leader, mediator, informative and problem solver. Recepoğlu [61] according to his study which examines school directors' who share sense of humor in the workplace and its effects on teachers' job satisfaction results with, the school directors who shared sense of humor in the workplace have more job-satisfied teachers than the school directors who shared less or didn't share at all. Indeed, in studies that examined the relationship between humor and school ambiance concluded that school directors using humor have an important role in the formation of healthy and moderate school ambiance [61-65].

As Şişman and Turan [12] state, the traditional roles and responsibilities of the contemporary of school directors have transformed into a new view consisting of different titles such as leadership, communication, group processes, curriculum development, teaching-learning processes, performance evaluation, etc. Hesapçığlu [13] states that the school director should be the person who starts the learning process and who, through enhancing teachers' abilities, creativities and devotion, supports teachers in the achievement of the goals of the school. Herrington [14] says that such a situation will suppress school directors, however, contemporary education directors are responsible for student success. School directors promote the improvement of the sense of justice by supporting teachers, providing source materials and promoting and controlling the use of these materials for the intended purpose $[15,16]$.

When some studies on the duties, roles and responsibilities of the school directors for a modern school are analyzed, it is stated that the roles of school directors, in general, are: as a teaching leader, to support teaching activities; to create a positive learning environment; to coordinate curriculum and activities; to create an effective school culture; to contribute to teachers' career development; to manage the curriculum; to participate in teamwork; to bear new responsibilities caused by the increasing pressure due to student success [17-29]. In performing these critical duties and in improving the quality of instruction, the school 
director must be a teaching leader in such duties as revising continually the applications in the school, giving help and support in the applications, and controlling the educational processes. According to Çubukçu and Girmen [30], in performing these duties and improving the quality of instruction, school directors must check up on teachers' performances continually.

In ISSCL (Interstate School Leaders Licensure Consortium Council of Chief State School Officers) 1996 report, it is stated that, among the standards related to the educational leadership of the school directors, the school directors should have the following characteristics: The school directors should advocate, improve and maintain curriculum and a school culture which will lead to professional development and to the learning of all of the students' success. The school directors should be able to make use of all resources that the school owns in order to create and maintain an effective learning environment [12, $13,15]$. Besides, curriculum development activities must be applied studies and be continuous, and most important of all, in order to fulfill the goals of the school, the school directors should have knowledge of the curriculum, should support the implementation of the curriculum through cooperation with teachers in the implementation of the curriculum and should control the suitability of the curriculum.

The opinions of the school directors related to their understanding and comprehension of the curriculum and their support in the implementation of the curriculum are of great importance both in increasing the quality of instruction and in increasing success of the school, accordingly. Moreover, such qualities of the school directors are also significant for schools to achieve their objectives, for the continuity of the curriculum development and for the realization of the expectations from the school directors in the national and international levels. It is important for an effective school that the school directors should have knowledge about the curriculum that they should cooperate with the teachers in the applications, that they should guide and support teaching applications, and that they should control and evaluate curriculum applications.

This study aims at determining the school directors' opinions related to educational curriculum. In order to achieve this goal, different attitudes and behaviors of school directors such as their recognition, comprehension and explanation of the curriculum of the courses their schools provide, their evaluation, guidance and support in the applications of the curriculum, and their control of the suitability of the teaching activities will be analyzed. In this sense the opinions and behaviors of school teachers related to recognition, comprehension and support and controlling of curriculum applications has great role in increasing school success, and it is hoped that this study will contribute to the literature on this subject and to the increment of school success. In addition, through this study, the levels of school directors' knowledge on the curriculum, the support they provided for the application of curriculum and their inspection activities will be determined.

\subsection{Research Problems}

In the scope of this study, the analysis of the opinions of the school directors related to their recognition, comprehension and explanation levels of the curriculum, their support in the application of curriculum, and their inspection of the implementation of the curriculum will be performed in the context of the answers given to the following questions:

1. What do you know about recognition, comprehension and explanation of the educational curriculum?

2. What kind of support do you provide in the application of curriculum? Specify the support you have provided and the reasons why you have provided such support.

3. While applying the curriculum, what have you done related to your inspection duty? Write down with the reasons.

\section{Method}

This study is conducted with a qualitative research approach. This approach offers a very special opportunity to focus on a subject or situation [66-68]. In this context, this study is designed in accordance with the qualitative research design. The qualitative researches, querying through specific methods, try to make sense of problems related to social life and men [31].Considered in this respect, the qualitative research is a technique in which the researchers investigated facts and events in their natural environments, and in which they make sense of and interpret the facts and events they analyzed [32].

\subsection{Research Design}

The analysis of the opinions of school directors related to the curriculum to increase the quality of instruction is the main goal of this study. In this study, phenomenological research design, which is a qualitative research design, is applied. The phenomenological research design is used in cases which are well known but a deep comprehension cannot be attained. The aim here is to define the individuals' experiences related to facts and events and the meanings they load them. Phenomenological researches try to explain the meaning of the phenomena, concepts and experiences. Their aim is to search for different thoughts, perceptions and reactions. They advocate that the reality is not in the physical appearance but in the behaviors and experiences of the individuals [31, 33, 34].Phenomenological researches may not put forward precise and generalizable results appropriate to the structure of qualitative researches, but may contribute to the literature and application through putting forth some 
samples, explanations and experiences which will lead us to understand and comprehend a phenomenon better [32]. Therefore, in this study, phenomenological research design is used since the subject of this study is to make sense of the experiences and the behaviors of school directors related to their comprehension of curriculum, their support in the application and their inspection task in the implementation of the curriculum.

\subsection{Research Group}

This study, in the 2014-2015 academic year was carried by participation of school directors who are directing secondary schools such as; science high schools, social science high schools, Anatolian high schools and vocational high schools. While determining the school directors, simple sampling method is used and the study is carried out through simple negotiations with the school directors of the secondary school in the city center of Isparta. After 28 of the secondary school directors accepting the meeting request, the study group is composed by those school directors. Firstly, an appointment with each school director is requested. . Upon the approval of each school director, an interview was made at the specified hour, and the data were recorded. Personal characteristics of the interviewed school directors are as follows:

5 of the 28 interviewed school director were women and 23 of them were men. 22 of them have a Bachelor's Degree and 6 of them have a Master's Degree. As for their directorship experience, 6 of them have 1-5 years of directorship experience, 3 of them 6-10 years, 12 of them 11-15 years, 3 of them 16-20 years and 6 of them 21 years and over. 15 of the interviewed school directors work in Vocational High Schools, 9 of them work in Anatolian High Schools, and the remaining 4 school director work in Science High School, Social Sciences High School, Sports High School and Fine Arts High School. To keep secret those school directors' identity, codes between M1-M28 are used.

\subsection{Data Collection Tool}

Interview is defined as a predetermined mutual and interactive communication process based on asking questions and answering style for a serious purpose [32]. In this study, a semi-structured interview form consisting of three basic questions is used as data collection tool along with the interview technique in which the probing of these questions are made. The interview form consists of two parts: The first part consists of the questions about the sex, education level and directorship seniority of the school directors. The second part consist of the questions directed to the school directors and related probing questions. The interviews are conducted in the offices of the school directors and are written records are taken by the researcher. The questions which constitute the basis of this research and the probing concepts along with the questions are as follows:

1. What do you know about the recognition, comprehension and explanation of the curriculum applied in your school?

2. What kind of support do you provide in the implementation of the curriculum? Define the support you provide and explain the reasons.

3. What do you do related to your task of controlling the application of curriculum? Explain with the reasons.

\subsection{Data Gathering and Analysis}

Data analysis is the process of exporting the meaning of the data. Exporting meaning of the data involves; reduction, integration and interpretation of what people are saying and what researchers are seeing and telling [67]. The data collected in this study were analyzed through content analysis. Content analysis requires an in-depth analysis of the data collected and provides the opportunity to reveal new themes and aspects that didn't exist before [32, 65].

In this study, for analyzing of data, four main phrases are handled. Those phases are (1) Coding data (2) Determining themes (3) Regulation of codes and themes and (4) Identification and interpretation of findings. In the first phase, the interview forms recorded during the interview are analyzed one by one in terms of the questions asked to the participants. Answers given to each question, the data that constitutes a meaningful integrity in itself and the meaning derived from the data are coded first. The coded data is converted to the code list, by this way the code list has fulfilled the key element for the examination and organization of the data. In the second phase, based on the codes (concepts) achieved, themes are created according to the similarities of the codes. While themes are created, codes are gathered first, and then themes are created the common aspects of the codes into consideration. In the third phase, the data is arranged according to the resulting codes and themes. The first hand data is presented to the reader in such a way that the reader may understand, identify and explain the data he reads. In the last phase, findings are explained, cause-effect relations are established, some results are derived from these relations, and some significant explanations are made. To help to ensure the validity and the security of the analysis, research data are examined in depth by different researchers, obtained categories are compared and agreed categories were recognized as research themes. Moreover, due to direct quotations are considered effective in reflecting the views of the individuals in qualitative assessments [66], some data obtained in qualitative assessment has been transmitted without any interpretations. In analyzing and modeling research data, "QSR NVivo10" software is used.

\subsection{Reliability and Validity}

In researches, "validity" is related to the accuracy and "reliability" is related to replicability of the scientific findings [32]. Experts have been consulted in order to provide the reliability and validity in this study. In this regard, firstly, the opinions of the experts have been made use of in the preparation of the interview form, and discussions with 
the experts have been made whether the questions in the interview form will collect data that will serve the purpose of the this research. Then, in the meetings organized for the confirmation of the data, the researcher has informed the experts about the process orally, and presenting the collected data and the results of the study to the experts, the researcher has evaluated the validity of his own approach and way of thinking together with the experts and reached a consensus. The consistency of the data is evaluated in terms of (consensus and dissidence), and calculated using the formula (Consensus/Consensus+Dissidence)x100) [6]. According to the calculations, the percentage of minimum consensus is $80 \%$ and the maximum is $100 \%$.

\section{Results}

This section consists of the findings obtained through the analysis of the data collected for the purpose of this study. Analyzed through the research questions, findings have been presented in figures, and significant explanation, comments and evaluations have been given place in this section.

\subsection{Recognition, Comprehension and Explanation Levels of School Directors}

For the purposes of this research, the first question asked to the school directors is the question of what they know about the curriculum. They are informed that they can answer this question in line with the elements of curriculum and with the question to which curriculum seeks an answer. The answers of the school directors related to curriculum and the meanings of these questions are shown in Figure 1 as branch codes obtained using Nvivo computer software.

When Figure 1 is analyzed in terms of the elements of curriculum, it is seen that school directors referred to 'objective' with the percentage of $89 \%$ (25), to 'content' $54 \%$ (15), to 'learning situations' $57 \%$ (16) and to 'evaluation' $75 \%$ (21). According to these results, it is clear that all of the school directors, except for three of them, emphasized and given meaning to 'objective', one of the elements of curriculum. It is also clear that $75 \%$ of the school directors tried to give meaning and explain the element of 'evaluation' while almost half of the school directors tried to comprehend and explain the element of 'content' and 'learning situations'. Therefore, it can be deduced that the school directors don't recognize and comprehend the elements of the curriculum completely. In addition, it is clear that in terms of recognition and comprehension of curriculum, the school directors gave answers paying attention to the elements of curriculum.

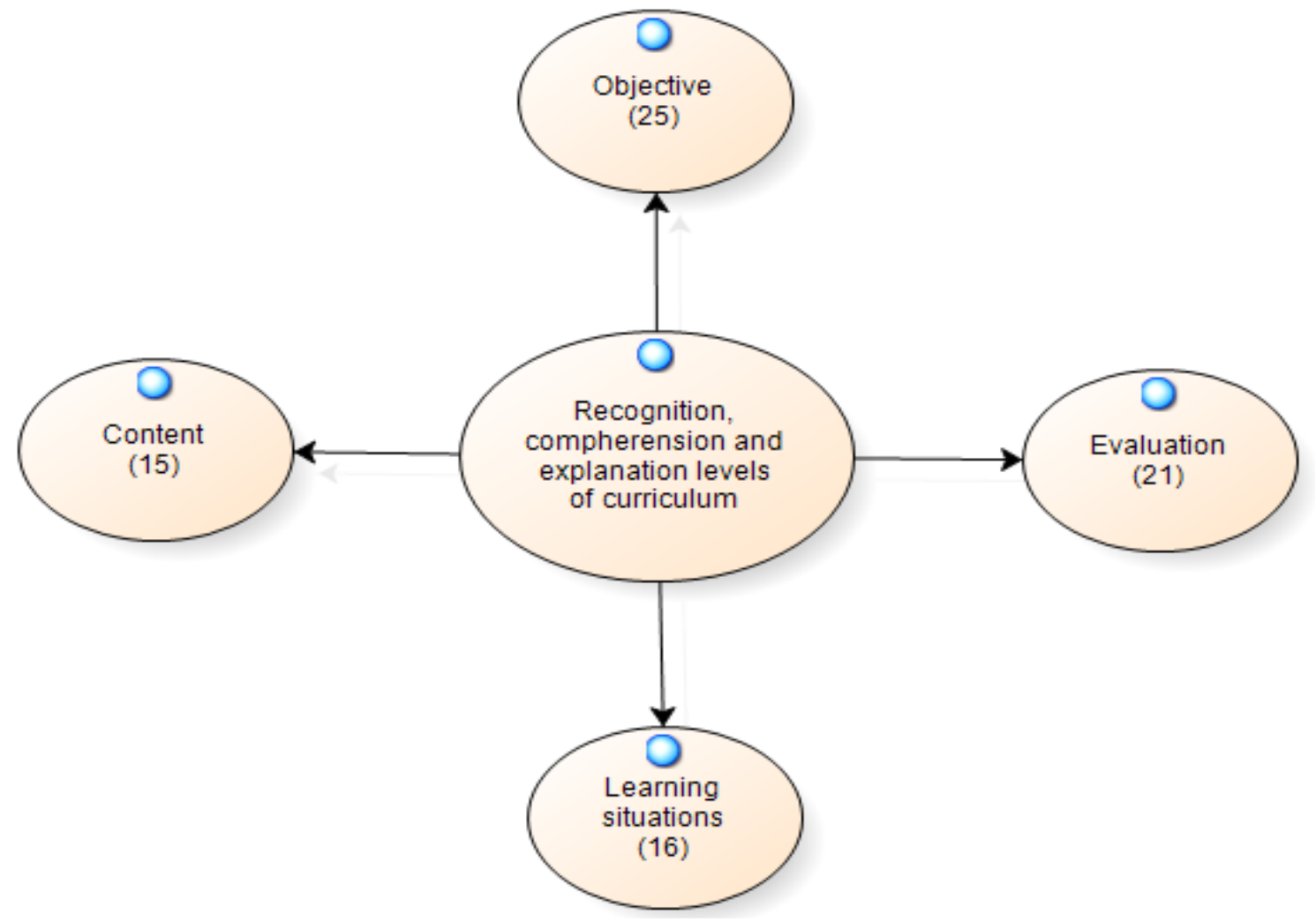

Figure 1. Recognition, Comprehension and Explanation Levels of School Directors. 
Some of the opinions of the school directors related to the levels of recognition, comprehension and explanation of the curriculum are as follows:

$S D$ \#2, "A curriculum consists of objective, content, learning situations and evaluation. The teaching objectives cover the objectives and achievements of the course along with the behavioral changes that should be brought about in the students. It is very important to take the conditions of the school and the environment in to consideration in order to actualize these behavioral changes. Paying attention to these conditions, teaching process is performed using suitable methods and technical educational tools. However, Exam-based evaluation creates a big problem. For me, university entrance exams, in particular, create important obstacles in bringing in the course contents."

$S D$ \#8, "In our school, process-based curriculums are applied for the last 8 or 10 years instead of the previously applied behavior-based curriculums. In our schools, the objectives of National Education in general and course objectives in particular are tried to be achieved. Each course is authentic in terms of its content which spreads through the years with its helix-structured subjects. Moreover, the subjects have the qualities that will lead to science, society, technology, environment-based, scientific research process and skills."

$S D \# 20$, "A curriculum should be considered in terms of objectives and means. The objectives of the curriculum and the educational objectives of the country should support each other. These objectives can be associated with the specific objectives of the course. The achievements of the curriculum are the objectives and the subjects are the means. A teacher who thinks that he has successfully transferred the subjects considers himself as successful. However, in my opinion, he may be more successful if he conducts an acquisition-oriented lesson."

According to the answers the school directors gave to the questions related to the recognition, comprehension and explanation of the curriculum, it is seen that they tried to comprehend and explain the course curriculums in line with the elements of the curriculum. The directors brought the objectives and achievements in the foreground about curriculum, and they emphasized 'evaluation', highlighting the problems related to it. In addition, they also handled 'content' through objective-subject relation. It is clear that they tried to explain 'learning situations' through emphasizing the teaching-learning process. Hence, it can be said that the directors drew attention to elements of the curriculum and that they tried to comprehend and explain the curriculums in this respect. Although all the school directors must recognize and comprehend the elements of the curriculum, it is seen that some school directors did not mention two or more of the elements and almost half of the directors did not mention some of the elements. So, it can be concluded that the school directors do not recognize and comprehend the curriculum enough.

\subsection{Supports Given for the Implementation of the Curriculum by the School Directors}

The second question asked to the school directors is about the kind and reasons of the supports they provided related to the implementation of the curriculum. In connection with this question, the school directors are also asked questions about how they provided support in such situations as the achievement of teaching goals, the organization of content and unit, the preparation of teaching plan, the determination of the teaching techniques, methods and approaches, providing teaching tools, creating learning environment and the determination of teaching level. The answers the school directors gave and the branch codes obtained using Nvivo computer software is given in Figure 2.

Figure 2 demonstrates the opinions of the school directors related to their support in the implementation of the curriculums. According to the supports which were provided by school directors in the implementation of the curriculum, support in providing teaching tools takes the first place (23, $82 \%$ ). As for the other supports, the citation percentage of the supports given in planning teaching and content organization is $71 \%(20)$, in creating and improving the learning environment is $64 \%$ (18), in conducting meetings with the teacher, supporting, encouraging and guiding them is $60 \%$ (17), in cooperating with private sector and following the latest developments is $32 \%$ (9), in conducting in-service-training and vocational education seminars is $29 \%$ (8) and in measurement and evaluation is $25 \%$ (7). The least cited ones are the supports given in cooperation with the teachers and communication $(6,21 \%)$ and in the determination of the teaching techniques, methods and approaches $(6,21 \%)$. Some of the opinions of the directors related to the support they provided are given below:

$S D$ \#5, "It is important, especially in vocational and technical education, to learn through seeing, experimenting and doing. So, in collaboration with the teachers, I provide the teaching materials which students need in the workshops and practical courses from Ministry and private sector. Content and unit organization is the basis of an effective teaching. I suggest teachers to be prepared for the lesson and to make a plan, and I help teachers as much as possible. I provide collaboration between the teachers. I follow the innovations and developments in the sector and I inform teachers. I encourage teachers to participate in the trainings. If the learning environments do not meet the needs we cannot achieve quality."

SD \#15, "It is the basis of our understanding of management to support our teachers in the issues of teaching plans, teaching tools and other teaching activities, while they are implementing the curriculum, that is, carrying out educational activities. I try to meet their need without creating any difficulty. I support them, because it is the teacher who implements the curriculum. It is also our duty to provide support in accordance with his/her plan. Of course we conduct informative meetings whenever we see some deficiencies. Besides, information related to such 
deficiencies is given especially through the vocational seminars performed at the end of semester."

$S D \# 18$, "In the effective implementation of the curriculums, for me, there are three basic factors: 1 . Teaching tools and environments, 2. Efficient teachers, and 3. Students eager to learn. According to this, in our strategic plans, we aim at creating better learning environments: creating a better classroom environment, a better laboratory, a better practice environment and a better sports field. Firstly, I want a list of the tools needed and then I try to supply these tools. Proper teaching environments will make learning and teaching more effective. Supported teacher becomes efficient. Proper teaching environments will create desire in students for learning."

When the opinions of the directors are analyzed, it is seen that the directors created teaching environments and met the needs of the teachers according to their requirements and that the directors tried to do these with the opportunities provided by the Ministry of National Education and private sector. Moreover, it can be said that the implementation of the curriculums is important, that the implementers of the curriculums are the teachers, and that the deficiencies arises during the implementation is tried be eliminated through meetings and seminars. In addition, it is clear that the school directors put an emphasis on the opinions related to the idea that proper teaching environments was necessary for an effective teaching and that proper environments increased teaching efficiency and created desire in students for learning. Besides, it can be inferred that the directors supported, guided and encouraged teachers for an effective teaching. All these demonstrate that the director have provided important supports in respect of providing teaching tool, improving teaching environments, guide and encourage teachers and making teaching plans.

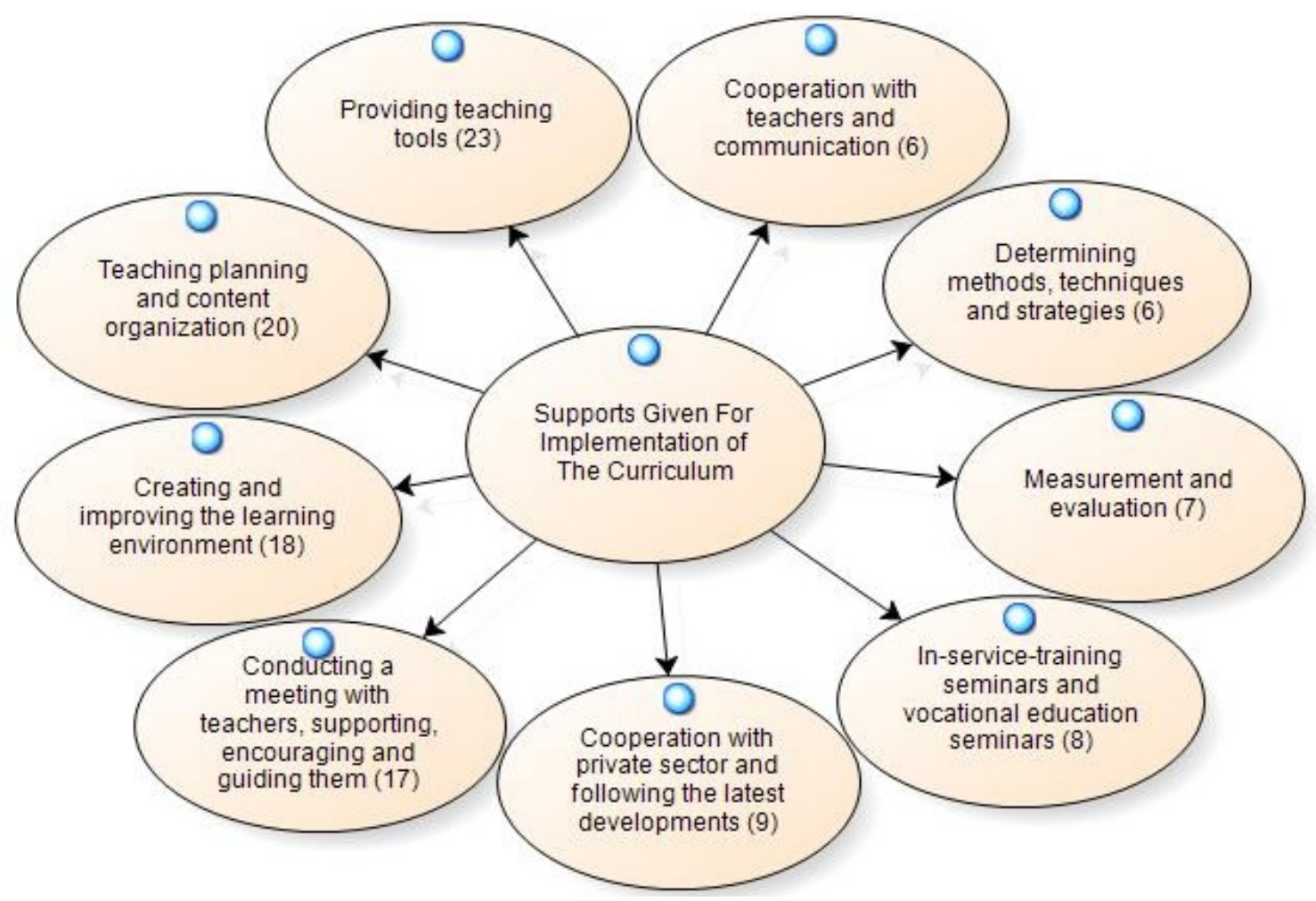

Figure 2. The opinions of the school directors related to supports given for the implementation of the curriculum. 


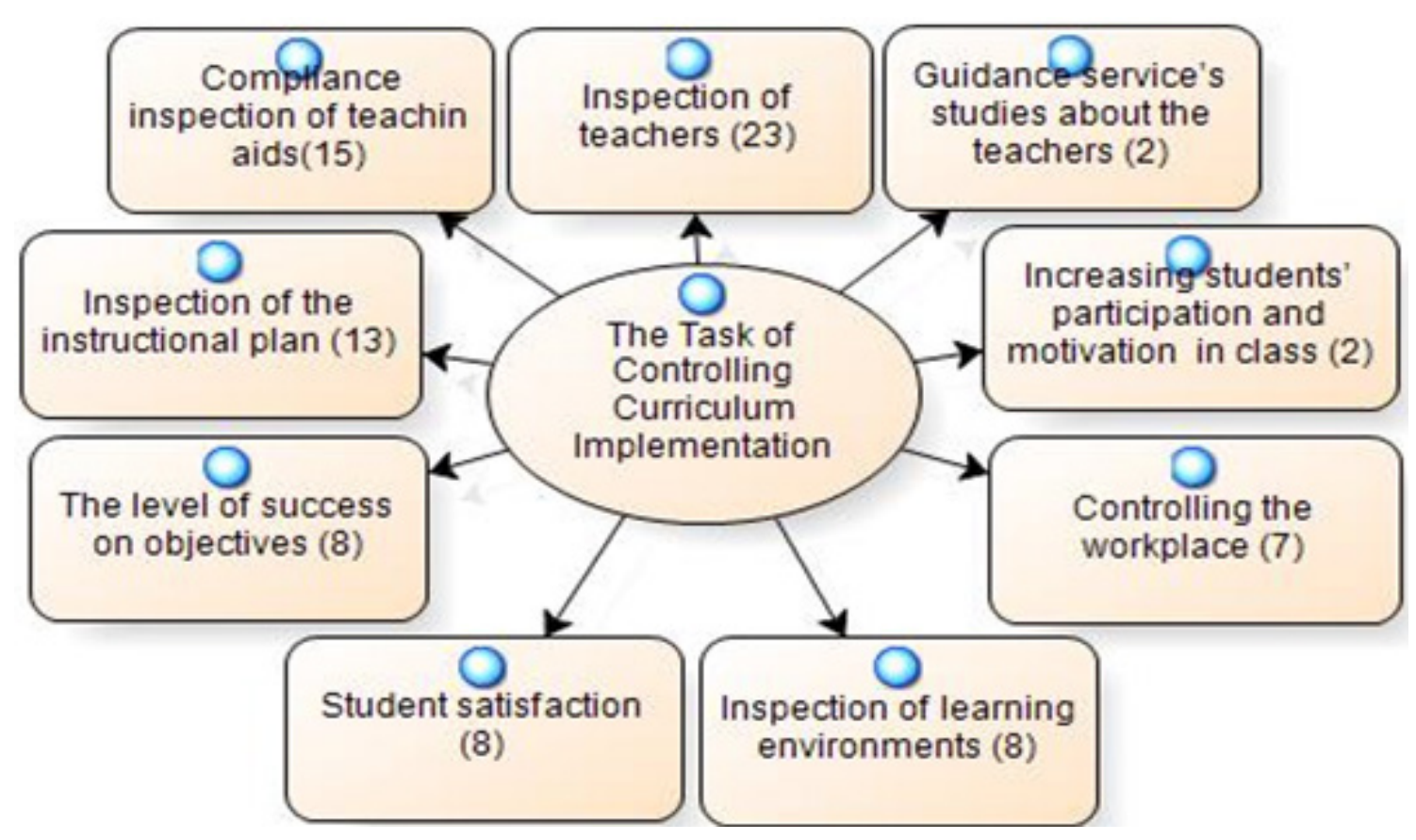

Figure 3. The opinions of the school directors related to their task of controlling curriculum implementation.

\subsection{The Opinions of School Directors Related to Their Task of Controlling the Curriculum Implementation}

The last question asked to the school directors is about their task of controlling the implementation of the curriculums and about the reasons. In line with this questions, the directors were asked some probing questions like what kind of tasks they performed in order to control the teaching objectives and evaluation of teaching plans, the appropriateness of teaching approaches, techniques and methods, the appropriateness of teaching environments, and the sufficiency and appropriateness of tools. Answers given to these questions and the branch codes, related to controlling tasks, obtained using Nvivo software is presented in Figure 3.

When Figure 3, which shows the school directors' tasks of controlling the implementation of the curriculum, is analyzed, it is seen that inspection of the teachers has the highest citation (23, 82\%). 15 school directors (54\%) cited controlling task of the appropriateness of the teaching environment and tool, 13 school directors $(46 \%)$ cited the task of controlling the teaching plans, and 8 school directors $(29 \%)$ cited the tasks of controlling the level of success on objectives, student satisfaction and the inspection of the teaching environment. Related to the school directors' task of controlling, the first striking controlling task is the inspection of the teachers. Then, it is seen that the school directors inspected the appropriateness of teaching environment and tools. Besides, it can be said that the tasks of controlling of teaching plans and controlling of the level of success on objectives were cited substantially. Some of the opinions of the school directors related to their task of controlling the implementation of the curriculum are as follows:
$S D$ \#9, "Effective teaching is possible through effective learning environments. In this respect, the first thing, I think, I should do is to inspect the availability of appropriate teaching environments. For this reason, I inspect the environments like classroom environment, laboratories, workshops, etc. in respect of tools and teaching materials. In accordance with the relevant legislation, I attend the classes each teacher and I try to evaluate what teachers do-not do related to teaching objectives and achievements in terms of efficiency. One of the most important tools, even the road maps, in the implementation of the curriculums is the teaching plans, activity plans. I control the originality of teaching plans, since these plans are mostly downloaded from the internet and slight changes are made on the downloaded plans. Such a situation leads the teacher to laziness, and the teacher finds it difficult to implement the plan he/she did not prepare. This reduces the teaching efficiency. When such situations are faced, teachers should be made to prepare their own plans."

$S D \# 17$, "In the inspections we performed, as the administration, we constantly exchange ideas with our teachers and students. Whenever we see a defect, we conduct meetings with our teacher, determine a strategy and try to correct deficiencies. The success of the curriculums is depends on the improvement of teaching environments, on the provision of required tools for each course, on the preparedness of the teachers for the courses and on the teaching activities performed by the teachers to meet the objectives. Teachers are forced to make exam-based evaluations especially because of the university entrance exams. In this respect, we also inspect our teachers in terms of making exams which will provide the achievements of teaching objectives. However, our teachers are think that they need much help on this issue. So, we conduct seminars." 
SD \#24, "As a director, I inspect the teaching environments of my school. If there is a lack of tools and materials, I observe and then I organize meetings with my teachers about this issue. I attend the classes of teachers, I inspect whether they teach according to the teaching plan, and I observe the classroom activities of the students. I want branch teachers to conduct lessons in cooperation. I try to control the exams and provide execution of the joint exams which consists of questions that will correctly measure teaching objectives. With the perception that the success will be the success of all of us, I appreciate and encourage my teachers."

When related opinions of directors are considered, it is understood that among the controlling tasks the school directors emphasize, the inspection of teachers in classroom environment is the first and that the inspection of teaching environments and the inspection of tools is the second. We can say that the next controlling tasks are the conduction of teaching activities deliberately and the conduction of proper evaluation. Therefore, in respect of the task of controlling the implementation of the curriculum, it can be said that the school directors focused on their tasks of controlling including the inspection of teachers, the appropriateness of teaching environments and tools, the ensuring of the preparation of teaching plan, the ensuring of the evaluation appropriate to teaching objectives and the determination of student satisfaction.

\section{Discussion}

According to the results obtained in this study, related to the recognition, comprehension and explanation of the curriculum, it is seen that the school directors try to recognize, comprehend and explain the curriculum in terms of the elements of the curriculum. The result is positive about objectives of the curriculum and the evaluation of the curriculum whereas it can be considered negative in terms of content and learning situations. The results can be associated with the amount of the citations to the elements of the curriculum by the school directors (Figure 1). For instance; $89 \%$ of the school directors (25) cited objectives and $75 \%$ of the school directors (21) cited evaluation. It is possible to evaluate these results as positive. The citation percentage of content is $54 \%$ (15) and the citation percentage of learning situations is $57 \%$ (16). In terms of the success that can be achieved from the curriculums, it can be thought-provoking that almost half of the school directors did not cite content and learning situations, and that they are unaware of half of the elements of curriculum. It reveals clearly that the school directors are inadequate in curriculums since none of the directors mentioned all the elements of curriculum in their opinions related to their level of recognition, comprehension and explanation of the curriculum. For an effective and successful school, this situation may lead to negative consequences in terms of the support the school directors provide in the implementation of the curriculum and in terms of their controlling task of the implementation of the curriculum.

Considering the findings related to the support the school directors provided in the implementation of the curriculums, it is seen that the directors provided support in providing teaching tools $(23,82 \%)$, in planning teaching and content organization $(20,71 \%)$, in creating and improving the learning environment $(18,64 \%)$, in conducting meetings with the teacher, supporting, encouraging and guiding them $(17,60 \%)$, in cooperating with private sector and following the latest developments $(9,32 \%)$, in conducting in-service-training and vocational education seminars $(8$, $29 \%$ ) and in measurement and evaluation (7, 25\%), in cooperation with the teachers and communication and in the determination of the teaching techniques, methods and approaches $(6,21 \%)$. The results can be associated with the amount of the citations to the support given by the school directors (Figure 2). In terms of the supports the school directors provided in providing teaching tools, in planning teaching and content organization, in supporting, encouraging, motivating and guiding the teachers, in collaborating with the teachers and in following innovations and developments, it can be inferred that the school directors have provided significant support. It is clear that, in the implementations of the curriculum, the appropriateness and the sufficiency of teaching tools and environments is very important, and support should be provided on this issue. The most important support that should be provided in the application of the curriculums to the teachers who are the implementers of the curriculums are the support of teaching environments and teaching tools. One of the most important supports provided in increasing the efficiency of teaching is the conduction of teaching activities deliberately and the content organization. The number of the directors who stated that they have provided such supports is at a rate that cannot be underestimated $(71 \%)$. It can be said that this is an important finding.

School directors can be educational leaders, and they must be. The educational leaders who have experience, moral commitment and strong leadership skills may turn their schools into teaching centers. This is the result of their leadership qualities. At the same time, to create an efficient teaching environment in the school and to talk to the teachers, the students and the other staff frequently and evaluate the situations are among the expected duties of an educational leader. Especially, talking to teacher about the issues related to education, sharing experiences, making guidance, appreciating and encouraging will be influential in increasing the success of the school. The result of the study related to the support given in the implementation of the curriculums (conducting meetings with the teachers, seminars, encouraging, guiding, creating effective teaching environments, student satisfaction, etc.) will help the school be learning environment and will make the school be a teaching center, an environment which will provide learning for everyone, that is to say, it will help the school be a learning environment not only for the students but for the 
teachers and for all the stakeholders as well. These results overlap with the view that the school directors' talking to the teacher about their professional experiences and estimating their opinions will increase the success of the school and have positive effects on the quality of education $[37,38]$. In accordance with the results of this study (conducting meetings with students and paying attention to student satisfaction, Gurr, Drysdale and Mulford [28], in their study, state that the talks between the school directors and the students related to educational topics are effective in student's developing a sense of identity and self-confidence. Thus, these results can be evidence that the results obtained through this study emphasize important points.

School directors' communicating with teachers, students, and other staff with a humorous approach affect the success of the school. Studies such as [14, 22, 45, 61-65] showed that humorously speaking done by school directors increases students' and teachers' performance by providing an effective communication and enhancing them a sense of belonging. The results derived from the research such as collaboration with teachers, conducting a meeting with them, encouraging and guiding them will be able to provide important contributions in terms of increasing the performance of the teachers and creating a positive school climate. In addition, it is stated that school directors have a crucial role together with teachers, students and other staff in creating an efficient school culture [45, 52-57]. In order to form a decent school culture, it's significant that school directors should make all his employees feel valued. One of the best ways of achieving that is school directors should taking into consideration the roles and expectations of its employees and establishing a realistic communication with them. Also Fullan [5] and [40], demonstrated that a positive communication affects academic success. Besides, Çelikten [22] and Printy [41] focuses on the importance of the positive interaction between school directors and teachers in the process of increasing the quality of education. From the results it can be said that the research supports collaboration with teachers, creating a positive learning environment, collaboration with private sector and following the latest developments. Once again, some research claimed that positive communication and support for collaboration behaviors increase the success of the school and teaching [7, $15,42,43]$. Results related to the support of school directors for curriculum is similar with the results of studies in the literature. These results may be a proof that the results obtained from the research emphasize significant points. School directors' effective communication culture and school culture they generated in the school may provide an effective relationship and cooperation among all. It is possible to say that all these results gives importance to research enrich it.

The effective communication culture which the school directors create may lead to an effective relationship and cooperation between everyone in the school. [39, 40, 43] suggest that positive communication affects school success. Likewise, Printy [41] points out the importance of the effect of positive interaction between the teachers and the directors in the process of improving teaching quality. It can be said that these results support the results of this study in terms of the collaboration with the teachers, the creation of an effective teaching environment, the collaboration with the private sector and following the innovations. In addition, according to the findings of some researches, the positive approaches of the school directors toward positive communication and collaboration increase school success and success of education [7, 15, 41-43, 46]. All these results not only show the importance of but also add value to the results of this study.

Considering the findings related to the school directors' task of controlling the implementation of the curriculums, it is seen that the school directors have fulfilled their tasks of inspection the teachers $(23,82 \%)$, inspecting the appropriateness of teaching environments and tools (15, $54 \%$ ), inspecting teaching plans $(13,46 \%)$, inspecting the level of the achievement of objectives and inspecting student satisfaction $(8,29 \%)$. It is possible to say that, the results can be associated with the amount of the citations to the tasks of inspection by the school directors (Figure 3). The most striking task related to the school directors' tasks of controlling is that of inspection of teachers. What follows inspection of the teachers is the inspection of teaching tools and teaching environments. related to their the tasks of controlling, it is seen that a considerable amount of the school directors also cited the inspection of teaching plans and the inspection of the achievement level of objectives. Some studies relating to the inadequacy of the physical facilities of the school [69] and Canbazoğlu etc. [57], they stated that inadequate physical conditions negatively affect academic activities. There is no doubt that in schools, provided adequate physical conditions, educational activities will be carried out in a better way. The results of this study and also a great majority of the school director group support that school directors should examine the physical conditions of the school and support teacher correcting those physical deficiencies.

These results demonstrate that the school directors have carried out significant duties in terms of their physical inspection tasks like the improvement of teaching environments and the provision of hardware needs along with their inspection tasks related to formal rules like the process of planning and the achievement level of teaching objectives. Yilmaz [44] emphasizes that the borders of the school directors' tasks of controlling related to curriculums should be expanded to inspect the classroom activities of the teachers and to improve the educational activities through establishing a close relationship with the teachers. According to the results obtained, it is evident that the school directors participating in this study are inadequate in terms of curriculum since all the participating school directors did not cite all of the inspection and controlling tasks, or only some of them did so. However, without waiting the improvements in inadequate physical conditions, it should be noted that the work should be carried out in the best possible way in the 
current circumstances. As Çelik [45] states, it would be unrealistic to expect from the school directors who do not have a training related to educational management to perform their roles appropriately. A successful school director should use the power granted to him as not to disturb the staff working with him and by being an idealist, he should be a model for his personnel. It can be said that, in addition, a school director should create an environment which enables employees take place voluntarily and contribute extra effort for success of the school and instead of using all his authority by himself, he should share it with his employees.

\section{Conclusions}

According the obtained results related to the opinions of school directors in terms of their levels of recognition, comprehension and explanation of curriculum, it is seen that school directors are familiar with 'objective' (\%89), with 'content' (54\%), with 'learning situations' (57\%) and with 'evaluation' (75\%).From the findings related to the support the school directors provided in the implementation of the curriculums, it can be deduced that the school directors have provided support in supplying teaching tools, in planning teaching and content organization, in improving the teaching environment, in conducting meetings with the teachers, in encouraging, supporting and guiding them, in cooperating with the private sector, in following the novelties, in conduction in-service training and vocational seminars, in evaluation, in the determination of strategy, method and technique, in communication and in collaborating with the teachers. When the findings related to the school directors' task of controlling, it is clear that they give priority to fulfill their controlling tasks like inspecting the teachers, inspecting the appropriateness of teaching environment and tools, inspecting teaching plans, inspecting the appropriateness and achievement level of objectives, inspecting student satisfaction and inspecting the teaching environment.

\section{Suggestions}

In the light of the findings obtained, the following suggestions can be made in order to contribute to the practice and literature on this subject:

- Courses and workshops related to the process of curriculum development, the support to be provided in the implementation of curriculums and the tasks of controlling to be carried out in the implementation of curriculums should be included in the process of training school directors.

- In the process of determination and employment of school directors, their competence related to curriculums should be taken into account.

- The competence of school directors related to their recognition, comprehension and explanation of curriculums, the support they should provide in the implementation of the curriculums and their tasks of controlling the implementation of the curriculums should be improved through in-service training.

- The competence of school directors related to their recognition, comprehension and explanation of curriculums, the support they should provide in the implementation of the curriculums and their tasks of controlling the implementation of the curriculums should be inspected.

- School directors should be encouraged and rewarded in terms of their competence related to curriculums.

\section{REFERENCES}

[1] Lezotte, L. W. Principal insights from effective schools. Education Digest, 58(3), 14-17, 1992.

[2] Johnson, J. F. Expert noticing and principals of high-performing, Urban schools. The Johnson, J.F. (1997). Whatever it takes! IDRA Newsletter, 24(6). Retrieved January 28, 2004, fromhttp://www.idra.org/Newslttr/1997/Jun/ Joseph.htm Journal for the Education of Students Placed at Risk, 1-33, 2011.

[3] Murphy, J., \& Hallinger, P. The principal ship in an era of transformation. Journal of Educational Administration, 30(3), 77-88, 1992.

[4] Brown, J. Leadership for school improvement. Emergency Librarian, 20(3), 8-20, 1993.

[5] Fullan, M. The change leader. Educational Leadership, 59(8), 16-20, 2002.

[6] Haberman, M. Creating effective schools in failed urban districts. Education News.org. Retrieved January 22, 2004, fromhttp://www.educationnews.org/creating-effective-schoo ls-in-failed.htm. 2003

[7] Leithwood, K., Day, C., Sammons, P., Hopkins, D., \& Harris, A. Successful school leadership: What it is and how it influences pupil learning. (Tech Rep. RR800), 2006.

[8] Çelikten, M. Okul örgütü ve yönetimi. V. Çelik (Ed.), Türk eğitim sistemi ve okul yönetimi (s.121-140). Ankara: Pegem Akademi, 2010b.

[9] Dinham, S. Principal leadership for outstanding educational outcomes. Journal of Educational Administration, 43(4), 338-356, 2004.

[10] Robinson, V. M. J., Lloyd, C., \& Rowe, K. J. The impact of leadership on student outcomes: an analysis of the differential effects of leadership type. Educational Administration Quarterly, 44(5), 635-674, 2008.

[11] Lezotte, L. Correlates of effective schools: The first and second generation. Okemos, MI: Effective Schools Products, Ltd. 1991.

[12] Şişman, M., \& S. Turan. Eğitim ve okul yönetimi, Eğitim ve Okul Yöneticiliği. (Editör: Yüksel Özden). Pegem A Yayıncılık, Ankara, 2004. 
[13] Hesapçıŏlu, M. Postmodern çağdaş eğitim yönetimi ve eğitim örgütü. Türkiye'de EğitimYönetimi, İstanbul: Kültür Koleji EğitimVakfı Yayınları, s.97-103, 1998.

[14] Herrington, C. D., \& Wills, B. K. "Decertifying the principal ship: The Politics of Administrator Preparation in Florida". Educational Policy, 19 (1), 181-200, 2005.

[15] Harris, A. Distributed leadership and school improvement. Educational Management Administration \& Leadership, 32(1), 11-24, 2004

[16] DfES (UK, Department for education and skills). (2007). Price waters coopers report, London, DfES. Retrieved on 28.05.2015.

[17] Aydın, M. Eğitim yönetimi. Ankara: Hatiboğlu, 1994

[18] Vandenberghe, R. Thinking about principals: How they cope with external pressures and internal Redefinition of Their Role. International Journal of Educational Research, 29: 371-380, 1998.

[19] Whitaker, K. S. Principal Role Changes and Implications for Principal Candidates. International Journal of Educational Reform, 8 (4): 352-362, 1999.

[20] Özdemir, S. Eğitimde örgütsel yenileşme. (5. Baskı). Ankara: Pegem A, 2000.

[21] Bakioğlu, A. Özcan, K., \& Hacifazlığlu, Ö. Okul yöneticilerinin mentor yoluyla yetiştirilme ihtiyacı. 21. Yüzyıl EğitimYöneticilerinin Yetiştirilmesi Sempozyumu, Ankara, 2002.

[22] Çelikten, M. Okul kültürünün şekillendirilmesinde müdürün rolleri. Gazi Üniversitesi Türk Eğitim Bilimleri Dergisi, 4(1), $1-17,2003$.

[23] Marsh, D., \& Lefever, K. School principals as standards-based educational leaders. Educational Management, Administration \& Leadership, 32 (4): 387- 404, 2004.

[24] Mestry, R., \& Grabler, B. R. The training and development of principals to manage schools effectively Using Competence Approach. International Studies in Educational Administration, 32 (3): 2-19, 2004.

[25] Svedberg, L. Rhetorical Resources for Management. Educational Management, Administration \& Leadership, 32(4): 423-438, 2004.

[26] Van Voorhis, F., \& Sheldon, S. Principals' roles in the development of US programs of school, family and community partnership. International Journal of Educational Research, 41: 55-70, 2004.

[27] Cerit, Y. Okul ve öğretmenlik içinde. M. D. Karslı (Ed.), Öğretmenlik mesleğine giriş. Ankara: Pegem A. 2005.

[28] Gurr, D., Drysdale, L., \& Mulford, B. Models of successful principal leadership. School Leadership and Management, 26(4), 371-395, 2006.

[29] Çelikten, M. A Perspective on women principals in Turkey. International Journal of Leadership in Education (8)3, 207-221, 2005.

[30] Çubukçu, Z., \& Girmen, P. Ortaöğretim kurumlarının etkili okul özelliklerine sahip olma düzeyleri. Sosyal Bilimler Dergisi, (16), 121-136, 2006.
[31] Mayring, R. Nitel sosyal araștırmaya giriș. (Çev., A. Gümüș \& M.S. Durgun), Adana: Baki Kitapevi. 2000.

[32] Yıldırım, A., \& Şimşek, H. Sosyal bilimlerde nitel araştırma yöntemleri. Ankara: Seçkin Yayıncılık. 2008.

[33] Creswell, J.W. Qualitative inquiry and research design: Choosing among five traditions. Thousand Oaks, CA: Sage. 1998.

[34] Frankel, J.R., \& Wallen, N.E. How to Design and Evaluate Research in Education. McGraw Hill. New York, 2006.

[35] Strauss, A. L., \& Corbin, J. Basics of qualitative research: Grounded theory procedures and techniques. Newbury Park, CA: Page, 1990.

[36] Glaser, B. G. Theoretical sensitivity: advances in the methodology of grounded theory. Mill Valley, Ca: Sociology Press, 1992.

[37] Cotton, K. Principals and student achievement. Melbourne: Hawker Brown low Education, 2003.

[38] Waters, J. T., Marzano, R. J., \& McNulty, B. Leadership that sparks learning. Educational Leadership, 61(7), 48-51, 2004.

[39] Fullan, M. Leading in a culture of change. San Francisco: Jossey-Bass. 2001.

[40] Wubbels, T., Creton, H., \& Hooymayers, H. Review of research on teacher communication styles with use of the leary model. Journal of Classroom Interaction, 27(1) 1-11, 1992.

[41] Printy, S. M. Leadership for teacher learning: A community of practice perspective. Educational Administration Quarterly, 44(2), 187-226, 2008.

[42] De Maeyer, S.,Rymenans, R., Van Petegem, P., Bergh, H., \& Rijlaarsdam, G. Educational leadership and pupil achievement: the choice of a valid conceptual model to test effects in school effectiveness research. School Effectiveness and School Improvement, 18(2), 125-145, 2007.

[43] Ross, J. A., \& Gray, P. School leadership and student achievement: the mediating effects of teacher beliefs. Canadian Journal of Education, 29(3), 798-822, 2006.

[44] Y1lmaz, K. Okul müdürlerinin denetim görevi. İn̈nü Üniversitesi Ĕgitim Fakültesi Dergisi, Nisan, 10 (1): 19-35, 2009.

[45] Çelik, V. Okul kültürü ve yönetimi. Pegem A Yayınları, Ankara, 1997.

[46] Çelikten, M. Roles of principal in shaping school culture. Education and Science, (31)140, 56-61, 2006b.

[47] Austin, G. R. and Holowenzak, S. P. An Examination of 10 Years of Research on Exemplary Schools, in Gilbert R. Austin and Herbert Garber (ed.). Research on Exemplary Schools, pp. 65-82. Orlando: Academic Press. 1985.

[48] Arnn, J. W. and Mangieri, J. Effective Leadership for Effective Schools: A Survey of Principals' Attitudes. NASSP Bulletin, 72(505), 1-7, 1988.

[49] Levine, D. U. \& Lezotte, L. W. Unusually effective schools. A Review and Analysis of Research and Practice. UW-Madison: The National Center for Effective Schools, 1990. 
[50] Balc1, A. Etkili Okul ve Okul Geliştirme: Kuram, Uygulama ve Araştırma (Geliştirilmiş ikinci baskı). Ankara: Pegem A Yayınc1lık, 2001.

[51] Buluç, B. İlköğretim Okullarında Bürokratik Okul Yapısı ile Okul Müdürlerinin Liderlik Stilleri Arasındaki İlişki. Eğitim ve Bilim, 34(152), 71-86, 2009.

[52] Busher, H. and Barker, B. The crux of leadership: Shaping school culture by contesting the policy contexts and practices of teaching and learning. Educational Management Administration Leadership, 31(1), 51- 65, 2003.

[53] Peterson, K. D. and Deal, T. E. How leaders influence the culture of schools, Educational Leadership, 56: 28-30, 1998.

[54] Şahin-Fırat, N. Okul müdürü ve öğretmenlerin okul kültürü ile değer sistemlerine ilişkin algıları. Eğitim ve Bilim, 35(156), 71-83, 2010.

[55] O'Connor, P. J. Administrative support of counseling programs: Defining it and measuring it. Journal of College Admission, 177(1), 13-19, 2002.

[56] Myrick, R. D. Developmental guidance and counselling: A Practical Approach (4th Ed.). USA: Educational Media Corporation, 2003.

[57] Canbazoğlu S., Eroğlu B. \& Demirelli H. Okul Müdürlerinin Fen ve Teknoloji Dersine İlişkin Çalışmalarının Değerlendirilmesi. Kastamonu Eğitim Dergisi, 18(3), 759-774, 2010.

[58] Hallinger, P. and Murphy, J. The Social Context of Effective Schools. American Journal of Education, 94(5), 328-355, 1986.

[59] Gümüşeli, A. İ. Çağdaş okul müdürünün liderlik alanları. Kuram ve Uygulamada Eğitim Yönetimi, 28, 531-548, 2001.

[60] Çelikten, M. Bir okul müdürünün günlüğü. Fırat Üniversitesi Sosyal Bilimler Dergisi, 14(1), 123-135, 2004.
[61] Recepoğlu E. Okul Müdürlerinin mizah yeteneğinin öğretmenlerin iş doyumlarına etkisi. Ĕgitim ve Bilim, 33(150), 74-86, 2008.

[62] Ziegler, V. \& Boardman, G. Humor: the seventh sense in leadership. National Forum of Educational Administration and Supervision, 2(2), 11-15, 1986.

[63] Pierson, P. R. and Bredeson, P. V. It's not just a laughing matter: school principals' use of humor in interpersonal communications with teachers, Journal of School Leadership, 3: 522-533, 1993 .

[64] Koonce, W. J., III The relationship between principals' humor styles and school climate in elementary schools. Doctoral dissertation, George Washington University (Dissertation Abstracts International, 58, 1522), 1997.

[65] Yılmaz, K. Okul yöneticilerinin mizah tarzlarının çeşitli değişkenler açısından incelenmesi. İnönü Üniversitesi Ĕğitim Fakültesi Dergisi, 12(1), 27-44, 2011.

[66] Yin, R. K. Case Study Research Design and Methods. SAGE Publications. 1994.

[67] Merriam, S. B. Qualitative Research and Case Study Applications in Education. San Francisco: Jossey-Bass Publishers, 1998.

[68] Miles, M. B. \& Huberman, A. M. An Expanded Sourcebook: Qualitative Data Analysis, 2nd edition, Thousand Oaks, CA: Sage, 1994.

[69] Arı, A. Taşımalı İlköğretim Uygulaması (Uşak Örneği). Gazi Eğitim Fakültesi Dergisi, 23(1), 101-115, (2003.

[70] Özdemir, S. Eğitimde örgütsel yenileșme. 5. Baskı. Ankara: Pegem A Yayıncılık, 2000. 